\title{
COVID-19 Pandemisinin Hisse Senedi Piyasalarına Etkisi: Vaka ve Ölümlerin Yoğun Olduğu Ülkeler ile Türkiye İncelemesi
}

Kübra SAKA ILGIN*

Salim Sercan SARI ${ }^{* *}$

$\ddot{\mathbf{O} z}$

Aralık 2019'da ortaya çıkan ve yaklaşık bir yıldır devam eden COVID-19 Koronavirüs salgını dünyayı etkisi altına alarak küresel sosyo-psikolojik ve finansal krize neden olmuştur. Bu çalışmanın amacı COVID19'a bağlı toplam vaka ve ölüm sayılarının en fazla olduğu ülkelerde ve Türkiye'de toplam günlük vaka ve ölüm sayıları ilebu ülkelere ait hisse senedi piyasaları arasında nedensellik ilişkisi olup olmadığını araştırmaktır. Yöntem olarak Toda-Yamamoto nedensellik analizinin kullanıldığ 1 çalışmada 18.02.2020 ile 30.09.2020dönemine ait günlük veriler kullanılmıştır. Sonuç olarak inceleme dönemi itibariyle COVID19Koronavirüspandemisine bağlı dünyada en fazla toplam günlük vaka ve ölüm sayısına ulaşan ilk 5 ülke olan ABD, Hindistan, Brezilya, Rusya ve Kolombiya ile Türkiye'de gözlenen toplam vaka ve ölüm sayılarından hisse senedi piyasalarına doğru nedensellik ilişkisi olduğu görülmüştür.

Anahtar Kelimeler: COVID-19, Koronavirüs, Pandemi, Hisse senedi piyasası, Nedensellik.

\section{The Impact of COVID-19 Pandemic on Stock Markets: Investigation of Countries with Intensive Case and Deaths and Turkey}

\begin{abstract}
TheCOVID-19Coronaviruspandemic, whichemerged in December 2019 and has beenongoingforabout a year, has affectedtheworldandcausedglobalsocio-psychological and financial crisis. The aim of this study is to investigate whethert here is a causality relationship between daily total case and death numbers and stock markets of the countries that seen widely daily total case and death numbers dependent on COVID-19. In the study it is used theToda-Yamamoto causality analyzes method, daily data forth eperiod of 18.02.2020 and 30.09.2020 wereexploited. As a result, it was determined that there are causality from total case and death numbers to stock market swhich all selected countries that reached the top 5 daily total case and death numbers dependent on COVID-19Coronavirus pandemic in theworld; US, India, Brasil, Russia and Colombia and alsoTurkey.
\end{abstract}

Keywords: COVID-19, Coronavirus, Pandemic, Stock market, Causality.

Geliş/Received: 19. 10. 2020

Kabul/Accepted: 22. 12. 2020

* Bu çalışma, insanlardan veri ve örnek toplamayı gerektiren, anket, inceleme, alan çalışmasıı ve deney içeren araştırmalar 'kapsamına girmediğinden etik kurul onay belgesi gerektirmemektedir.

*Dr. Öğr. Üyesi, Erzincan Binali Yıldırım Üniversitesi, Bankacılık ve Finans Bölümü, kubra.saka@erzincan.edu.tr, ORCID: 0000-0001-5797-9617

** Arş. Gör. Dr., Erzincan Binali Yıldırım Üniversitesi, İşletme Bölümü, salim.sari@erzincan.edu.tr, ORCID: 00000003-2607-5249

(Makale türü: Araştırma makalesi) 
Kübra SAKA ILGIN, Salim Sercan SARI

COVID-19 Pandemisinin Hisse Senedi Piyasalarına Etkisi: Vaka ve Ölümlerin Yoğun

Olduğu Ülkeler ile Türkiye İncelemesi

\section{Giriş}

Dünya genelinde binlerce insanın ölümüne yol açan salgın hastalıkların içinde bulunduğumuz yüzyılda çeşitliörnekleri bulunmaktadır. Bunlar; Severe AcuteRespiratorySyndrome-Şiddetli Akut Solunum Sendromu (SARS-CoV)-2002; H5N1 AvianInfluenza-(İnfluenzaKuş Gribi)-2009 ve Middle East RespiratorySyndrome-Orta Doğu Solunum Sendromu (MERS-CoV-2012) virüslerinin neden olduğu salgın hastalıklardır. Son olarak 2019 yılı sonlarında bu virüslerden farklı olduğu tespit edilen yeni tip bir koronavirüs (COVID-19) salgın hastalık olarak tanımlanmıştır (Üstün ve Özçiftçi, 2020).

COVID-19Koronavirüsü, ilk olarak 2019 yılının Aralık ayında Çin'in Hubei eyaleti, Wuhan şehrinde küçük bir pazarda ortaya çıkan bir salgın türüdür. Dünya Sağlık Örgütü bu salgını 12 Mart 2020 tarihinde 'pandemi' olarak ilan etmiştir. Salgının başlangıç noktası Çin olmasına rağmen, 10 Ekim 2020 tarihinde 200'den fazla ülkede 37 milyondan fazla onaylanmış COVID19 vakası ve ne yazık ki bir milyonu aşkın ölüm sayısı bulunmaktadır. Vaka ve ölüm sayıları her geçen gün artmaktave salgın tüm dünyayı etkisi altına almaktadır. COVID-19Koronavirüsü onlarca ülkede hızla yayılmaya devam etmektedir. 10 Ekim 2020 itibariyle vaka sayısı dikkate alınarak ele alınan verilerdeCOVID-19'un en çok etkilediği ilk on ülke sırasıyla ABD, Hindistan, Brezilya, Rusya, Kolombiya, İspanya, Arjantin, Peru, Meksika ve Fransa olduğu görülmektedir (worldometers). Dünyanın önde gelen ekonomilerinin COVID-19'dan bu denli etkilenmiş olması, pandeminin küresel ekonomiyi tahmin edilenden daha fazla etkileyeceğini gözler önüne sermektedir. Son derece hızlı ve karmaşık bir şekilde yayılan, bir milyondan fazlacankaybınayol açan pandemininoluşturduğuendişe ve panik ortamı tüm dünyada sosyal, kültürel ve ekonomik faaliyetleri etkilemeye başlamıştır. Salgının yayılımını engelleyebilmek amacıyla birçok ülkede sınırlar kapatılmış, uçuşlar iptal edilmiş, sokağa çıkma yasakları getirilmiş ve olağanüstü hal ilan edilmiştir. $\mathrm{Bu}$ süreçte uluslararası ticaret ve küresel ekonomi de pandemiden olumsuz etkilenmiştir. Çoğu ülkede birçok sektörde üretimler durma noktasına gelmiştir. Tüm bu olumsuz gelişmeler döviz kurlarını, ülke ekonomilerini ve finansal piyasaları içinden çıkılması her geçen gün zorlaşan bir darboğaza itmektedir.

Bir şirketin piyasa değeri, büyük ölçüde mevcut ekonomik durumuna ve gelecekteki görünümüne bağlı olduğu gibi, belirli bir ülkenin borsasında listelenen tüm şirketlerin değeri, o ülkedeki küresel ekonomik duruma ve gelecekteki görünümüne bağlı olacaktır. Bu durum, hisse senedi fiyatlarındaki değişikliklerin, piyasa tarafından meydana gelen veya beklenen ekonomik değişikliklerle ilişkili olduğu anlamını ortaya çıkarmaktadır (Peiro, 2016). Küresel finansal krizlerden önce yatırımcı aktörler yükselen ve düşen hisse senetlerini sürekli takip etmektedir. Yatırımcıların riskten kaçındıkları ve hisse senetlerinin oynaklığının risk yoğunluğunun bir 
ölçüsü olduğu kabul edildiğinden optimum bir yatırım kararı verebilmek için hisse senedi fiyatını etkileyen faktörler hakkında bilgi ve farkındalığa sahip olunması tavsiye edilmektedir. Hisse senedi fiyatını etkileyen faktörler ise çeşitli iç ve dış faktörlerile ilişkilendirilmektedir. COVID19 Koronavirüspandemisigibi beklenmedik durumlar dış faktörler arasında yer almaktadır (Sharif, Purohit ve Pillai, 2015).

Geçmişten bugüne yaşanan kriz dönemlerinde finansal piyasaların önemli bir göstergesi olan hisse senedi piyasaları finansal aktörlere ekonomik gidişat hakkında yararlı bilgiler sağlamaktadır. COVID-19Koronavirüs salgını ile birlikte yaşanan aşırı belirsizlik ve endişe ortamında hisse senedi piyasalarında önemli değişimler yaşanmıştır. Finansal aktörlerin duyduğu gelecek kaygısı dünyanın önde gelen borsalarında yüksek dalgalanmalara neden olmuştur. Günlük olarak yayınlanan COVID-19 vaka ve ölüm sayılarındaki veriler ışığında 30Eylül 2020 tarihi itibariyle en çok ölümün gerçekleştiği ilk beş ülke ve Türkiye hisse senedi piyasalarının ele alındığ etkilenmiştir. Belirtilen tarihte en çok ölümün yaşandığı ilk beş ülke sırasıyla ABD, Hindistan, Brezilya, Rusya ve Kolombiya'dır. ABD Dow Jones Endeksi salgının yayılmasıyla keskin düşüşler yaşamış ve Mart 2020'de son 3 yılın en düşük seviyesine gerilemiştir. Hindistan'ın gözde endeksi BSE Sensex Endeksinde salgın sürecinde yaşanan olumsuz gelişmelerden dolayı 2017 y1lından bu zamana en düşük seviye Mart 2020'de gerçekleşmiştir. Brezilya BovespaEndeksi ülkenin her tarafindan gelen COVID-19' a bağlı ölüm haberleriyle birlikte 2017 y1lından beri en düşük seviyesini Mayıs 2020'de yaşamıştır. Rusya'yı etkisi altına alan salgın MOEX Endeksi üzerinde 2020 Mart ayında yaşanan düşüşle beraber 2019 Mart ayından beri en düşük seviyesine inmiştir. Kolombiya'nın en önemli endeksi olan COLCAP Endeksi 2020 yılında yaklaşık yüzde 35 düşüşle Ekim 2020 ayında son 11 yılın en düşük seviyesini görmüştür. Türkiye'de işlem gören ve piyasa hacmi en yüksek olan BIST 100 Endeksi ise 2017 Mart ayından beri en düşük seviyesini Mart 2020'de görmüştür (Investing, 2020). Ülkelerin önde gelen piyasa endekslerindeki hareketlerden de anlaşılacağı üzere, tüm dünyayı etkisi altına alan COVID-19 salgınının küresel finansal piyasalarda da ciddi bir krize yol açtığ ifade edilebilmektedir.

Bu çalışma 18 Şubat 2020 tarihinden itibaren dünyada COVID-19 salgınına bağlı en çok vakanın gerçekleştiği ilk beş ülke ve Türkiye'deki vaka ve ölüm sayılarının bu ülkelerin hisse senedi piyasalarına etkisini değerlendirmeyi amaçlamaktadır. Çalışma, güncel verilere göre salgından en fazla etkilenen ülke piyasalarının araştırma konusu olması ve kullanılan analiz yönteminin daha önceki çalışmalardan farklı olması bakımından özgün bir çalışmadır. Bu kapsamda girişten sonra ilgili literatür taraması yapılmıştır. Devamında kullanılan veri seti ve yöntem açıklanarak analiz sonucunda elde edilen bulgulara yer verilmiştir. Son olarak sonuç kısmı ile araştırma sonlandırılmıştır. 


\section{Literatür}

Bu bölümde COVID-19Koronavirüs salgını süresince Türkiye ve Dünya'da yapılmış olan, salgının finansal piyasalara olası etkilerini inceleyençalışmalar taranmış ve özetlenmiştir.

Açıkgöz ve Günay (2020), yaptıkları çalışmada dünya ve Türkiye için ele alınan verilere göre maliyetleriele alarakpandemininsektörel olarak kısa ve uzun vadeli küresel ekonomik etkilerinin ilk tepkilerini göstermeyi amaç edinmişlerdir. COVID-19'un ekonomik sonuçlarını dikkate alarak var olan raporları ve tartışmaları özetlemiş ve bazı çıkarımlarda bulunmuşlardır. Bulgularda ise COVID-19pandemisinin çalışanlar, müşteriler, tedarik zincirleri ve finansal sistem üzerinde önemlinegatif etkileri olduğu ortaya çıkmıştır.

Albulescu (2020a), yaptığı çalışmasında COVID-19 rakamlarının ham petrol fiyatları üzerindeki olası etkisini incelerken finansal oynaklığın ve Amerika Birleşik Devletleri ekonomi politikasındaki belirsizliğin etkisini ölçmeyi amaç edinmişlerdir. COVID-19'un günlük yeni enfeksiyon vakalarının uzun vadede ham petrol fiyatları üzerinde önemli boyutta bir olumsuz etkisi olduğunu ARDL tahmini ile göstermiştir.

Albulescu (2020b), çalışmasında ise COVID-19'un uluslararası takip edilmesinin başlamasından 40 gün sonra, yeni enfeksiyon ve ölüm oranlarına ilişkin resmi rakamların finansal piyasaların oynaklık endeksine (VIX) olası etkisini incelemiştir. Bulgularda Çin'de ve Çin dışında duyurulan yeni vakaların VIX üzerinde karışık bir etkisi olmasına rağmen, ölüm oranının VIX endeksini olumlu etkilediğini göstermiştir.

Aslam, Mohmand, Ferreira, Memon, Khan, veKhan (2020), COVID-19'un 56 küresel hisse senedi endeksi üzerindeki etkisini karmaşık bir ağ yöntemi kullanarak analiz etmeyi amaçlamışlardır. Bulgularda, COVID-19 nedeniyle düğüm değişiklikleri biçiminde yapısal bir değişiklik, azalan bağlantı ve ağın topolojik özelliklerinde önemli farklılıklar ortaya koymuşlardır. Gelişmekte olan pazarların ağ yapısında, düğümlerin eşzamanlı davranmasıyla bir bulaşma etkisi de tespit etmişlerdir. Ayrıca coğrafi konumlandırmaya dayalı olarak dünya borsa ağında önemli bir kümelenme ve homojenliği ortaya koymuşlardır.

Baker, Bloom, Davis, Kost, Sammon ve Viratyosin (2020), yapmış oldukları çalışmalarında COVID-19 gelişmelerinin ABD'de borsa davranışındaki etkisiniincelemiş ve önceki salgınlar ile karşılaştırmalarda bulunmuşlardır. Bulaşıcı hastalık salgınlarına yönelik haberlerin etkisini değerlendirmek için otomatik veri ve gazete makalelerini ele almışlardır. COVID-19salgınının gelişmeleri ile ilgili bilgilerinbüyük bir çoğunlukla 24 Şubat 2020'den günümüze büyük günlük $\mathrm{ABD}$ borsa hareketlerinin baskın itici gücü olduğu sonucuna ulaşmışlardır. 
Barut ve Yerdelen Kaygın (2020), çalışmalarında Covid-19 toplam vaka sayısı ile Türkiye, İtalya, İspanya, Hollanda ve Çin borsa endeksleri arasında eşbütünleşme olduğu, Almanya, Fransa, Belçika, İsviçre, İngiltere ve ABD borsa endeksleri arasında ise eşbütünleşme olmadığını tespit etmişlerdir.

Beck (2020), çalışmasında COVID-19'un küresel finansal sistem veya küresel ekonomi üzerinde yakın gelecektene gibi sonuçlar doğurabileceği konusundaki olasılıkları belirtmişlerdir. Finansal sistemdeki olabilecekoperasyonelsıkıntılara odaklanmak, müdahaledebulunmaya hazır olduklarını açık bir şekilde göstererek finnansal piyasalara olan güveni güçlendirmek ve kuyruk riski olaylarını dikkate alarak, başarısız bankaların olabilecek müdahalelerine ve çözümlerine hazır olmak gibi önerilerini belirtmişlerdir.

Çetin (2020), yaptığı çalışmada koronavirüs salgınını Türkiye ekonomisi üzerindeki etkisi, hisse senedi borsa endeksi ve genel ekonomik faaliyetlerin düzeyi açısından incelemiştir. Ulaşılan bulgular, ele alınan dönemde sosyal mesafe ve sokağa çıkma kısıtlaması uygulamasının genel ekonomik faaliyetlerin seviyesini düşürdüğünü ancak hisse senedi fiyatları üzerinde olumsuz bir etkide bulunmadığını ortaya çıkarmıştır. Genel olarak ise sonuçlar, koronavirüs krizinin zirvede olduğu dönemde sokağa çıkma kısıtlaması, yurt içi seyahat kısıtlaması ve yurt dışı seyahat kısıtlaması uygulamaları ile para politikası kararlarının ve kamu harcamaları tutarının genel ekonomik faaliyetlerin seviyesiyle anlamlı bir ilişkide bulunduğunu ve etkilediğini meydana çıkarmıştır. Para politikası kararlarının kısa dönemde COVID-19pandemisinin etkilerini hafifletmede kamu harcamaları uygulamasından daha etkili olduğu belirtilmiştir.

Ekren (2020), çalışmasında dünya ekonomisi üzerinde büyük bir olumsuzluğa neden olan COVID-19pandemisi'nin İran İslam Cumhuriyeti'nin ekonomisi üzerine etkilerini ve İran'ın COVID-19 salgını karşısında ki var olan ekonomik kapasitesi ve aldığı tedbirlerden bahsetmiştir. Sonuçta İran hükümeti'nin, hızlı ve etkili bir yönetim oluşturamadığı takdirde, yakın gelecekte siyasi ve sosyal huzursuzluğa neden olabilecek önemli iş kayıplarıyla karşılaşılmasının olası olduğunu belirtmiştir.

Erik, Lombardi, Mihaljek veShin (2020), çalışmalarında dünyayı sarsan COVID-19 sürecinde Küresel Satın Alma Yöneticileri Endeksleri, dünya ticareti ve küresel finansal koşullarının parametreleri arasındaki ampirik ilişkiyi, geniş dolar endeksinden yola çıkarak araştırmışlardır. Doların reel ekonomik aktivite ve küresel ticaret üzerindeki etkisinin GSYİH'dan beri, VIX'in ise azaldığını belirtmişlerdir.

Göker, Eren ve Karaca (2020), çalışmalarında COVID-19pandemisinin Borsa İstanbul sektör endeks getirileri üzerindeki olası etkisini incelemeyi amaçlamışlardır. Çalışmada, salgından etkilenme durumunu sektör bazında ele almışlardır. BIST’te yer alan 26 sektöre ait verilerden hareketle yapılan olay çalışması bulgularına göre, araştırılan olay dönemlerinin 
çoğunda çoğu sektörün negatif Birikimli Ortalama Olağanüstü Getiriye (CAAR) ulaştığı, bazı dönemlerde ise farklı sektörlerin CAAR değerlerinin pozitif olduğu belirtilmiştir. En yüksek kaybın Spor, Turizm ve Taşımacılık sektörlerinde olduğu belirlenmiştir.

Güler (2020), çalışmasının amacı COVID-19Koronavirüs döneminde bankalara yapılan itiraz ve şikayetleri kategorilerine göre ayırarak müşteri beklentilerinin belirlemiş ve sektöre fayda sağlayacak çözüm önerileri sunmuştur. Nitel olarak yapılan araştırmada verilere ulaşıldıktan sonra referans kodunu kaydederek iletinin türünü belirlemiş ana konu ve alt konuyu saptamıştır. Analizler sonucunda banka müşterilerinin en çok bankaların ürün ve hizmetlerinden kredi kartları, krediler ve çağrı merkezileri konusunda ileti gönderdikleri sonucuna ulaşmıştır.

Gülhan (2020), COVID-19pandemisinin Borsa İstanbul üzerindeki etkisini belirlemeyi amaçlayan bu çalışmayı, günlük veriler ile kısa ve uzun vadeli tahminler kullanılarak hata düzeltme ve sağlam modeller kullanarak yapmıştır. Bağımlı değişken olarak BIST 100 endeksi, bağımsız değişken olarak ise COVID-19 ölüm oran1, döviz kuru, korku endeksi, bulaşıc1 hastalıklar ve sermaye piyasaları, oynaklık endeksi ve uluslararası hisse senedi endeksi kullanılmıştır. Bulgularda seçilen değişkenlerin eşbütünleşik olduğu belirlenmiş ve hata düzeltme modelinin tahmin edilerek uzun vadede düzeltme oranı tahmin edilmiştir. Sonuçlara göre, pandemi süreci, seçilen kontrol değişkenleri ile kısa ve uzun vadede BIST 100 üzerinde etkilemiştir.

Gümüş veHacievliyagil (2020), COVID-19'un ölüm ve vaka sayıları ile salgının en fazla etkilediği turizm ve ulaştırma sektörleri özelinde borsa endeksleri arasındaki ilişki incelenmişlerdir. COVID-19 hastalığının etkisini temsilen virüs dolayısıyla yaşanan günlük ölüm sayıları ve günlük virüse yakalanan hasta vaka sayılarını bağımlı değişkenler olarak almışlardır. İki ayrı model kurularak salgın ile virüsün etkisi altına aldığı Borsa İstanbul Turizm Endeksleri ve Ulaştırma Endeksleri bağımsız değişkenler olarak incelemişlerdir. Araştırma sonucunda vaka sayıları ile endeks serileri arasında anlamlı bir ilişki tespit edilemezken, salgındaki ölüm sayıları ile bağımsız değişkenlerin uzun dönemde eşbütünleşik olarak birlikte ters yönde hareket ettiği bulunmuştur.

Hacıevliyagil ve Gümüş (2020), çalışmalarında Covid-19'un en fazla vaka sayısının görüldüğü 10 ülkedeki (Türkiye, Brezilya, Fransa, Almanya, İngiltere, İtalya, İspanya, Rusya, Çin, ABD) ölüm ve vaka sayıları ile bu ülkelere ait borsa endeksleri arasındaki ilişkiyi incelemişlerdir. Sonuca bakıldığında ülkeden ülkeye farklılık olduğu, bazı ülkelerde Covid-19 ölüm ve vaka sayılarının farklı etkileşim sergilediği görülmüştür.

Kılıç (2020), çalışmasında COVID-19 Koronavirüs salgınının Borsa İstanbul sektör getirileri üzerindeki etkisini olay etüdü yöntemi aracılığıyla araştırmıştır. Yaptığı analiz 
sonucunda endekslerin çoğunda negatif anormal getirilerle karşılaşmıştır. Sektör bazlı yaptığ1 incelemede en yüksek negatif getirilerin turizm ve tekstil sektörlerinde, pozitif getirinin ise ticaret sektöründe olduğunu belirtmiştir.

McKibbin veFernando (2020), COVID-19'un getirdiği olas1 ekonomik sonuçları anlayabilmek için McKibbin ve arkadaşları tarafından 2003 ve 2006 yıllarında geliştirilen modeli genişleterek önümüzdeki yıl bu salgının nasıl gelişebileceğine dair yedi farklı senaryoyu incelemişlerdir. Söz konusu senaryolar bir salgının bile kısa vadede küresel ekonomiyi önemli ölçüde etkileyebileceğini göstermiştir. Bu senaryolarla özellikle sağlık sistemlerinin daha az gelişmiş ve nüfus yoğunluğunun yüksek olduğu daha az gelişmiş ekonomilerde halk sağlığ 1 sistemlerine daha fazla yatırım yapılmasının önlenebileceği maliyetlerin ölçeğini göstermişlerdir.

Onali (2020), çalışmasında dünya üzerinde etkisi her geçen gün artan COVID-19 vakalarının ve ilgili ölümlerin $\mathrm{ABD}$ borsası üzerine yapacağı etkisini ele alarak işlem hacminde ve oynaklık beklentilerinde değişikliklerle beraber haftanın günü etkilerini de incelemişlerdir. Sonuçta, COVID-19 krizinden büyük ölçüde etkilenen ABD ve diğer altı ülkedeki vaka ve ölüm sayısındaki değişikliklerin, Çin için bildirilen vaka sayısı dışında $\mathrm{ABD}$ borsa getirileri üzerinde bir etkisi olmadığını bulmuşlardır. VAR modelleri ile, İtalya ve Fransa'da bildirilen ölüm sayısının borsa getirileri üzerinde olumsuz etkiye sahip olduğunu ve VIX getirileri üzerinde olumlu bir etkiye sahip olduğunu açıklamışlardır. Şubat 2020'nin sonu itibariyle VIX'in borsa getirileri üzerindeki olumsuz etkisinin büyüklüğünün üç kat arttığı sonucuna ulaşmışlardır.

Özdemir (2020), COVID-19pandemisinin BIST sektör endekslerine etkisini araştırmayı amaçlamıştır. COVID-19 vaka ve vefat sayıları ile sektör endekleri arasındaki asimetrik ilişki Hatemi-J asimetrik nedensellik testi ile incelenmiştir. Bulgularda, COVID-19 vaka sayısındaki pozitif şokların mali endekste negatif şoka neden olduğu tespit edilirken, vefat sayısı ile mali endeks arasında nedensellik ilişkisi tespit edilememiştir. COVID-19 vaka ve vefat sayılarındaki pozitif (negatif) şok Teknoloji endeksinde pozitif şoka neden olmuştur. Sonuçlarda, COVID19pandemisinin Mali sektör endeksini olumsuz yönde etkilediği, Teknoloji sektör endeksini pozitif yönde etkilediği gösterilmiştir.

Öztürk, Şişman, Uslu ve Çıtak (2020), çalışmalarında COVID-19 salgınının finans piyasaları üzerindeki etkisini günlük verilerin sabit etkiler yöntemiyle incelemişlerdir. Bulgular, sektörel endekslerin Avrupa ve Dünya vaka sayılarındansa Türkiye'deki vaka sayılarından daha çok etkilendiğini belirtmişlerdir. COVID-19 salgınının olumsuz ekonomik etkileri en çok metal ürünleri ve makine sektörlerinde görülmüştür. Spor, bankacılık ve sigortacıllk sektörleri ise bu endüstrileri takip etmiştir. Ekonomik durgunluk olmasına rağmen ülkede yiyecek-içecek, toptanperakende satış ve gayrimenkul yatırım sektörlerinin ise salgından en az etkilenen sektörler olduğu sonucuna ulaşılmıştır. 
Şenol ve Zeren (2020), çalışmalarında 21 Ocak 2020 ve 7 Nisan 2020 tarihleri arasında COVID-19 salgınının küresel pazarlar üzerindeki etkisini incelemişlerdir. Küresel pazarları ise Morgan StanleyCapital International (MSCI) 'World, gelişmekte olan pazar, Avrupa ve G7 endeksleri tarafından ele almışlardır. FourierEşbütünleşme testi ile yaptıkları analizde, hisse senedi piyasaları ile COVID-19 arasında uzun vadeli bir ilişki olduğunu tespit etmişlerdir.

Tayar, Gümüştekin, Dayan veMandi (2020), çalışmalarında COVID-19pandemisinin Türkiye'deki sektörel etkilerini incelemek amacıyla Basit Lineer Regresyon analizi yapmışlardır. Türkiye'deki aktif vaka sayılarındaki günlük değişim bağımsız değişken olarak, BIST sektör endekslerindeki günlük değişim bağımlı değişken olarak kullanılmıştır. Sonuçta Türkiye'de COVID-19pandemisinin Elektrik, Ulaştırma, Mali, Sınai, Teknoloji sektör endekslerinde anlamlı ve olumsuz etkilere sahip olduğu gösterilmiştir. Ayrıca ele alınan 10 sektörde COVID19pandemisinin Ticaret sektörü hariç olmak üzere farklı anlamlılık düzeyinde olumsuz etkilerinin olduğu belirlenmiştir.

Zeren ve Hızarcı (2020), çalışmalarında COVID-19Koronavirüs salgınının borsalar üzerindeki olası etkilerini bulmayı amaç edinmişlerdir. Hem COVID-19 günlük ölüm ve vaka sayılarının, eşbütünleşme testi kullanılarak borsalar üzerindeki olası etkilerini incelemişlerdir. Sonuç olarak toplam ölümle incelenen tüm borsaların uzun vadede birlikte hareket gösterdiğinibelirtmişlerdir. Toplam vakaların SSE, KOSPI ve IBEX35 ile eşbütünleşme ilişkisi içerisinde olduğu ve bu vakaların FTSE MIB, CAC40, DAX30 ile eşbütünleşik olmadığını açıklamışlardır. Yatırımcıların borsa yatırımlarından kaçınmalarını, altın piyasalarına yönelmelerinin uzun vadede en optimumtercihlerden biri olduğunu belirtmişlerdir.

Zhang, Hu veJi (2020), küresel finans piyasalarında ülkeye özgü risklerin ve sistemik risklerin genel modellerini haritalamayı amaçlayarak COVID-19 salgınının borsa riski üzerindeki etkisinin basit ama orijinal bir istatistiksel analizini sunmuşlardır. Sonuçlar pandemiye yanıt olarak küresel finansal piyasa risklerinin önemli ölçüde arttığını göstermiştir. Ele alınan ülke grubundaki piyasalar ulusal düzeydeki politikalara ve pandeminin genel gelişimine farklı tepkiler verdiğinden, ülkelerin bu zorlukları yenmek için birlikte çalışmadığı gerçeği görülmüştür. Bu durumunda küresel toplulukta parçalanma eğilimine neden olacağı belirtilmiştir.

Bu çalışma, COVID-19 pandemisinin başladığı günden bugüne kadar en yoğun yaşandığ ilk beş ülkeyi ve bunun yanı sıra Türkiye'yi de kapsaması açısından ilgili literatürden farklılık göstermekte ve literatüre katkı sağlamaktadır. Ayrıca; bu süreçte gözlenen toplam vaka ve ölüm sayıları ile incelenen ülkelerin hisse senedi piyasaları arasındaki nedensellik ilişkisinin araştırıldığ bu çalışmada daha önce yapılan çalışmalarda kullanılan analizlerden farklı bir yöntem olan Toda-Yamamoto nedensellik analizinin kullanılmıştır. 


\section{Veri Seti ve Yöntem}

Bu çalışmada ele alınanverilerden; COVID-19 verileri worldometer.com adresinden, ele alınan ülkelerin hisse senedi kapanış fiyatı verileri investing.com adresinden günlük veri setleri halindeulaşılmıştır. Veri seti 18 Şubat 2020 ve 30Eylül 2020 dönemini kapsamaktadır.

Hisse senedi piyasalarını temsilen; Amerika için DOW-JONES endeksi, Hindistan için BSE-SENSEX endeksi, Brezilya için BOVESPA endeksi, Rusya için MOEX, Kolombiya için COLCAPve Türkiye için BIST-100 endeksi günlük kapanış fiyatları kullanılmışıı. Çalışmanın bağımsız değişkenleri ise ilgili ülkeler için COVID-19'a bağlı günlük toplam vaka ve toplam ölüm sayısı verileridir. Çalışmada kullanılan değişkenlerin büyüme oranları alınarak değişkenler analize tabi tutulmuştur. Çalışmanın analizi için Eviews 10 paket programından faydalanılmıştır.

Zaman serileri arasındaki nedensellik ilişkilerinin incelendiği çoğu akademik çalışmada Granger nedensellik analizi uygulanmaktadır. Granger'in (1969) çalışmasında belirttiği üzere; rassal bir X değişkeninin geçmişi, rassal bir Y değişkeninin geleceği hakkında daha iyi tahmin imkânı sağlıyorsa; $X$ değişkeni Y değiş̧keninin Granger nedenidir.

Fakat klasik Granger nedensellik testinin bazı eksiklikleri bulunmaktadır. Bunlar; sahte regresyon problemlerine yol açabilmesi ve ilgili $\mathrm{F}$ testi sonuçlarının, değişkenlerin düzey değerlerinde eşbütünleşik olmadıkça geçerli sayılmamasıdır. Ekonometri alanındaki gelişmeler, ekonomik zaman serileri arasındaki nedensellik testine alternatif olarak Engle ve Granger (1987) hata düzeltme modelini ve Johansen ve Juselius (1990) vektör oto regresyon hata düzeltme modelini geliştirmişlerdir. Toda ve Yamamato (1995) ise çalışmasında bu testlerin daha karmaşık olduğunu ve sıkıntı parametrelerinin değerlerine duyarlı olduğunu dolayısıyla sonuçlarının güvenilir olmadığını ortaya koymuştur. Bu doğrultuda Toda ve Yamamato (1995) tarafindan bütünleşik ve eşbütünleşik süreçlerle genişletilmiş seviye VAR modeline dayalı yeni bir nedensellik yöntemi geliştirilmiştir. $\mathrm{Bu}$ yöntemin avantaj1, değişkenlerin bütünleşme ve eşbütünleşme özelliklerini önceden test etmenin gerekli olmaması ve bu testlere dayalı olası önyargılardan kaçınmaktır (Gillani, Rehman ve Gill, 2009).

Toda ve Yamamato analizinde, VAR(k) modelinin parametrelerindeki kısitlamaları test etmek amacıyla ModifiyeWald (MWALD) testi kullanılmaktadır. Bu test ile sinırda k serbestlik derecesi ile asimptotik Ki-kare dağılımına sahip olan $\operatorname{VAR}\left(k+d_{\max }\right)$ modeli tahmin edilmektedir. Burada $\mathrm{k}$, VAR modelinin gecikme sayısı ve $\mathrm{d}_{\max }$, maksimum bütünleşme derecesidir.

Toda ve Yamamoto testi uygulanırken herhangi bir ön test uygulama koşulu bulunmasa da değişkenlerin maksimum bütünleşme derecelerini belirlemek amaciyla analizden önce ADF (AugmentedDickey Fuller) ve/veya PP (PhiliphsPerron) gibi birim kök testleri uygulanmaktadır. Bunun yanı sıra; bu analizin uygulanabilmesi için maksimum bütünleşme derecesinin optimal gecikme sayısından büyük olmaması gerekmektedir (Yenilmez ve Erdem, 2018). 
Toda ve Yamamotoprosedürünün uygulanmasında iki önemli adım bulunmaktadır. İlki; sistemdeki değişkenlerin maksimum bütünleşme derecelerinin $\left(\mathrm{d}_{\max }\right)$; ikincisiise değişkenlerin gecikme uzunluklarının (k) belirlenmesidir. Gecikme uzunlukları belirlenirken LR, FPE, AIC, SBC ve HQ gibi bilgi kriterlerinden yararlanılmaktadır. Belirlenen gecikme uzunluğuna göre VAR (k) modeli oluşturulup değişkenlerin maksimum eşbütünleşme sayıları belirlendikten sonra $\mathrm{p}=\left(\mathrm{k}+\mathrm{d}_{\max }\right)$ toplam gecikmelerle $\operatorname{VAR}(\mathrm{p})$ modelleri tahmin edilir. Üçüncü adım ise; Granger nedenselliğin belirlenebilmesi amacıyla $\operatorname{VAR}(\mathrm{k})$ modellerine Wald testinin uygulanmasıdır.

Toda ve Yamamoto (1995), Granger nedensellik testini Görünüşte İlişkisiz Regresyon (SeeminglyUnrelatedRegression-SUR) tekniğiyle iki denklem sistemini tahmin ederek geliştirmişlerdir. Model aşağıdaki gibi tanımlanmaktadır:

$$
\begin{aligned}
& Y_{t}=\alpha_{1}+\sum_{i=1}^{k+d} \gamma_{1 i} Y_{t-i}+\sum_{t-i}^{k+d} \gamma_{2 i} X_{t-i}+\varepsilon_{y t} \\
& X_{t}=\alpha_{2}+\sum_{i=1}^{k+d} \delta_{1 i} Y_{t-i}+\sum_{t-i}^{k+d} \delta_{2 i} X_{t-i}+\varepsilon_{x t}(2)
\end{aligned}
$$

Burada k optimal gecikme uzunluğunu; d maksimum bütünleşme derecesini ve $\varepsilon_{y t}$ ile $\varepsilon_{x t}$ ise beyaz gürültülü olduğu varsayılan hata terimlerini ifade etmektedir. Nedenselliğin yönünü belirlemek amacıyla uygulanan Wald testinin hipotezleri ise aşağıdaki gibi tanımlanmaktadır.

(a) (1) nolu denklemdeki $\gamma_{2 i} \neq 0$ ise; $X_{t}, Y_{t}^{\prime}$ 'nin Granger nedenidir.

(b) (2) nolu denklemdeki $\delta_{2 i} \neq 0$ ise; $Y_{t}, X_{t}$ 'nin Granger nedenidir.

Wald testi sonucunda hesaplanan test istatistiği tablo değerinden küçük ise hipotezler kabul edilmekte değil ise hipotezler reddedilmektedir.

\section{Bulgular}

Çalışmanın ampirik analizinde Toda-Yamamoto (1995) testi uygulanmıştır. Zaman serisi analizlerinin yapılabilmesi için gerekli ön koşul serilerin durağan olmasıdır. Serilerin durağanlıklarının test edilmesi Toda-Yamamoto testinin önkoşulu olmasa da analizin sonraki aşamasında gerekli olan maksimum bütünleşme derecelerinin belirlenmesi amacyyla değişkenlerin durağanlıkları incelenmiştir. Durağanlık sınamasının yapılabilmesi için; birim kök testi ile serilerin düzey değerlerinde ya da birinci farkları alındığında durağanlık koşulunu sağlayıp sağlamadıkları incelenmiştir. Nedensellik analizine geçilmeden önce serilerin birim kök içerip içermediklerini test etmek amacıyla Genişletilmiş Dickey-Fuller (ADF) testi kullanılmıştır. Tablo 1, analizde kullanılan tüm değişkenlerin AugmentedDickey Fuller (ADF) birim kök testi sonuçlarını göstermektedir. 
Tablo 1. Birim Kök Testi Sonuçları

\begin{tabular}{|c|c|c|c|c|}
\hline \multirow[t]{2}{*}{ Değişken } & \multicolumn{4}{|c|}{ ADF Birim Kök Testi (Trend\&Sabit) } \\
\hline & Seviye $\left(t_{\text {ist }}\right)$ & p olasılık değeri & 1.Fark $\left(t_{\text {ist }}\right)$ & P olasılık değeri \\
\hline ABD-DOWJONES & -17.716 & 0.000 & & \\
\hline T-vaka-ABD & -4.571 & 0.001 & & \\
\hline T-ölüm-ABD & -2.592 & 0.284 & -3.846 & 0.016 \\
\hline $\begin{array}{l}\text { HIINDISTAN- } \\
\text { BSESENSEX }\end{array}$ & -14.564 & 0.000 & & \\
\hline T-vaka-HİNDİSTAN & -2.846 & 0.183 & -3.879 & 0.015 \\
\hline T-ölüm-HİNDİSTAN & -3.294 & 0.071 & -13.299 & 0.000 \\
\hline BREZİLYA-BOVESPA & -16.769 & 0.000 & & \\
\hline T-vaka-BREZİLYA & -5.804 & 0.000 & & \\
\hline T-ölüm-BREZÍLYA & -3.887 & 0.014 & & \\
\hline RUSYA-MOEX & -12.398 & 0.000 & & \\
\hline T-vaka-RUSYA & -3.023 & 0.129 & -8.114 & 0.000 \\
\hline T-ölüm-RUSYA & -4.163 & 0.006 & & \\
\hline KOLOMBİYA-COLCAP & -6.118 & 0.000 & & \\
\hline T-vaka-KOLOMBİYA & -4.021 & 0.010 & & \\
\hline T-ölüm-KOLOMBİYA & -4.529 & 0.001 & & \\
\hline TÜRKİYE-BIST100 & -7.196 & 0.000 & & \\
\hline T-vaka-TÜRKİYE & -7.388 & 0.000 & & \\
\hline T-ölüm-TÜRKİYE & -5.180 & 0.000 & & \\
\hline
\end{tabular}

Tablo 1'de görüldüğü üzere ABD-DOWJONES ile T-vaka-ABD serileri seviyede ve Tölüm-ABD serisi ise birinci farkı alındığında durağanlaşmıştır. HİNDİSTAN-BSESENSEX serisi seviyede durağan iken, T-vaka-HINDISSTAN ile T-ölüm-HINNDISTAN serileri birinci farkları alındığında durağanlaşmıştır. RUSYA-MOEX ile T-ölüm-RUSYA zaman serilerinin seviyede durağan iken; T-vaka-RUSYA serisinin ise birinci farkı alındığında durağan hale geldiği görülmüştür. BREZILLYA, KOLOMBIYYA ve TÜRKIYYE için ele alınan tüm serilerin seviyede durağan oldukları belirlenmiştir.

Analizde kullanılan Toda-Yamamato nedensellik analizinin ilk aşaması için maksimum bütünleşme derecesinin belirlenmesidir. Tablo 1'de bulunan ADF Birim Kök Testi sonuçları seviye değerlerinde durağan olmayan tüm serilerin birinci farklarında durağanlaştı̆̆ını göstermektedir. Dolayısıyla kurulacak olan modellerden Model 1, 2 ve 4 için maksimum 
COVID-19 Pandemisinin Hisse Senedi Piyasalarına Etkisi: Vaka ve Ölümlerin Yoğun Olduğu Ülkeler ile Türkiye İncelemesi

bütünleşme derecesinin $\left(\mathrm{d}_{\max }\right)$ 1; Model 3, 5 ve 6 için ise maksimum bütünleşme derecesinin $\left(\mathrm{d}_{\max }\right)$ 0 olduğu belirlenmiştir.

İkinci aşama, kurulacak olan VAR modelleri için optimal gecikme sayılarının (k) belirlenmesidir. Aşağıda Tablo 2'de tüm VAR modelleri için çeşitli bilgi kriterlerine göre elde edilenoptimal gecikme sayıları belirlenmiştir. Gecikme sayıları belirlenirken ilgili gecikmelerde modellerin tanı testleri de dikkate alınmıştır. Bu testler; Şekil 1'de belirtilen ve modellerin AR Karakteristik Polinomlarının Ters Köklerini ifade eden grafikler ile Tablo 3 'te belirtilen Otokorelasyon LM Testi ve White Değişen Varyans Testleridir.

Tablo 2. VAR Modellerinde Optimal Gecikme Uzunluklarının Belirlenmesi

\begin{tabular}{|l|l|l|l|l|l|l|l|}
\hline Model & Gecikme & LogL & LR & FPE & AIC & SC & HQ \\
\hline $\begin{array}{l}\text { Model 1- } \\
\text { ABD }\end{array}$ & 8 & 954.486 & $53.8901^{*}$ & $1.51 \mathrm{e}-09^{*}$ & $-11.8051^{*}$ & $-10.2931^{*}$ & $-11.1908^{*}$ \\
\hline $\begin{array}{l}\text { Model 2- } \\
\text { HINDiSTA } \\
\text { N }\end{array}$ & 8 & 492.375 & $43.4550^{*}$ & $6.16 \mathrm{e}-07^{*}$ & $-5.79688^{*}$ & -4.25010 & $-5.16835^{*}$ \\
\hline $\begin{array}{l}\text { Model 3- } \\
\text { BREZILYA }\end{array}$ & 7 & 509.846 & $51.9703^{*}$ & $4.43 \mathrm{e}-07$ & -6.12202 & $-4.76709^{*}$ & $-5.57146^{*}$ \\
\hline $\begin{array}{l}\text { Model 4- } \\
\text { RUSYA }\end{array}$ & 7 & 615.361 & $59.5444^{*}$ & $1.15 \mathrm{e}-07^{*}$ & $-7.47430^{*}$ & $-6.13165^{*}$ & $-6.92877^{*}$ \\
\hline $\begin{array}{l}\text { Model 5- } \\
\text { KOLOMBI } \\
\text { YA }\end{array}$ & 455.096 & $35.4439^{*}$ & $7.70 \mathrm{e}-07^{*}$ & $-5.56778^{*}$ & -4.38679 & $-5.08788^{*}$ \\
\hline $\begin{array}{l}\text { Model 6- } \\
\text { TÜRKIYE }\end{array}$ & 8 & 682.637 & $21.0938^{*}$ & $4.65 \mathrm{e}-08^{*}$ & $-8.38121^{*}$ & -6.84152 & -7.75558 \\
\hline
\end{tabular}

LR: Ardışık Modifiye LR Testi, FPE: Son Tahmin Hatası, AIC: Akaike Bilgi Kriteri, SIC:

Schwarz Bilgi Kriteri ve HQ: Hannan-Quinn Bilgi Kriterlerini ifade etmektedir.

*İlgili bilgi kriterine göre belirtilen gecikmenin optimal gecikme uzunluğu olduğunu ifade etmektedir.

Tablo 2'de çeşitli bilgi kriterlerine göre elde edilen optimal gecikme uzunluklarının Model 1, 2 ve 6 için 8; Model 3 ve 4 için 7, Model 5 için ise 6 olduğu belirlenmiştir. Modellere ait gecikme uzunlukları Şekil 1 ve Tablo 3'te yer alan çeşitli tanı testleri ile desteklenmeye çalış1lmıştır. Şekil 1, belirlenen gecikme uzunluklarına göre oluşturulan modellere ait AR karakteristik polinomunun ters köklerini; Tablo 3 ise otokorelasyon ve değişen varyans test sonuçlarını açıklamaktadır. 
MODEL 1-ABD

MODEL 2-HINNDİSTAN

Inverse Roots of AR Characteristic Polynomial Inverse Roots of AR Characteristic Polynomial

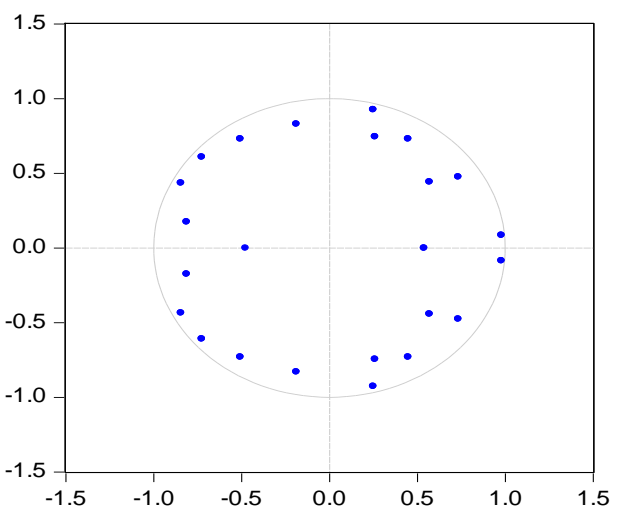

MODEL 3-BREZILYA

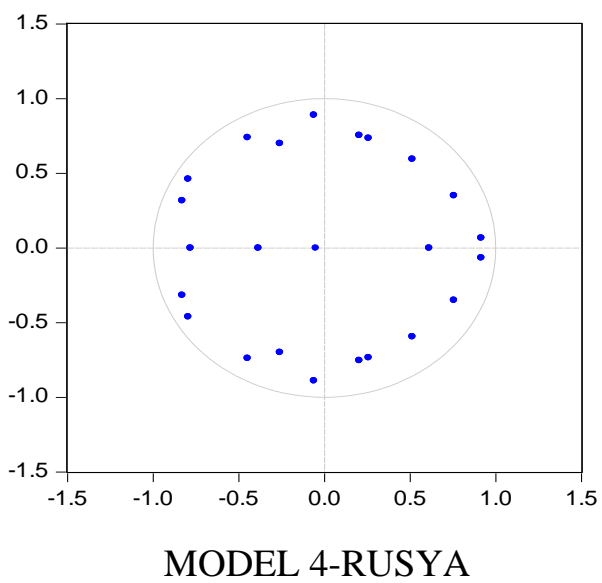

Inverse Roots of AR Characteristic Polynomial Inverse Roots of AR Characteristic Polynomial
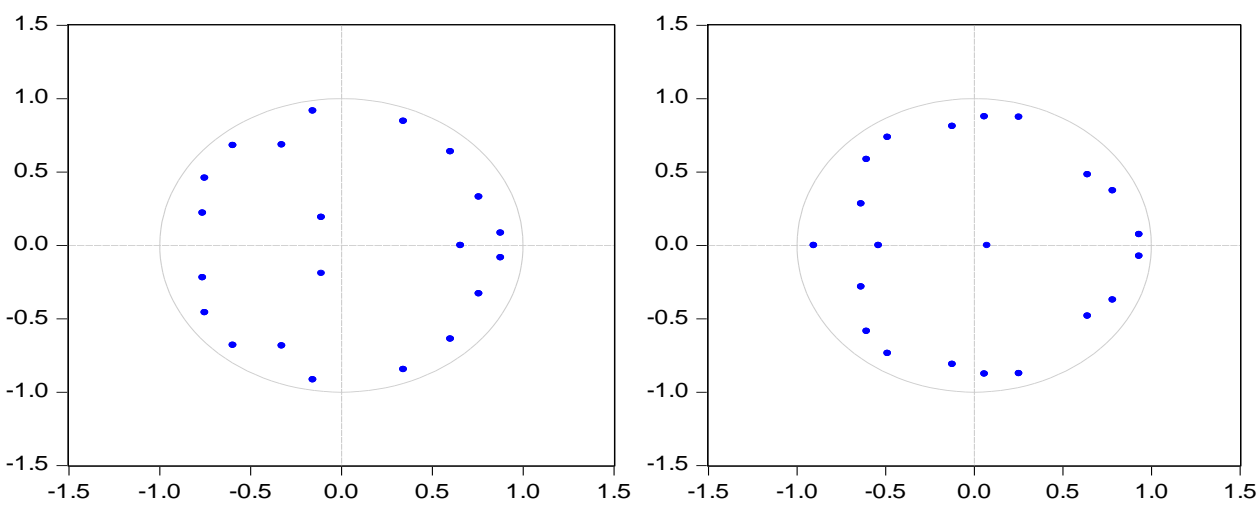

MODEL 5- KOLOMBIYYA

MODEL 6- TÜRKIYE

Inverse Roots of AR Characteristic Polynomial Inverse Roots of AR Characteristic Polynomial
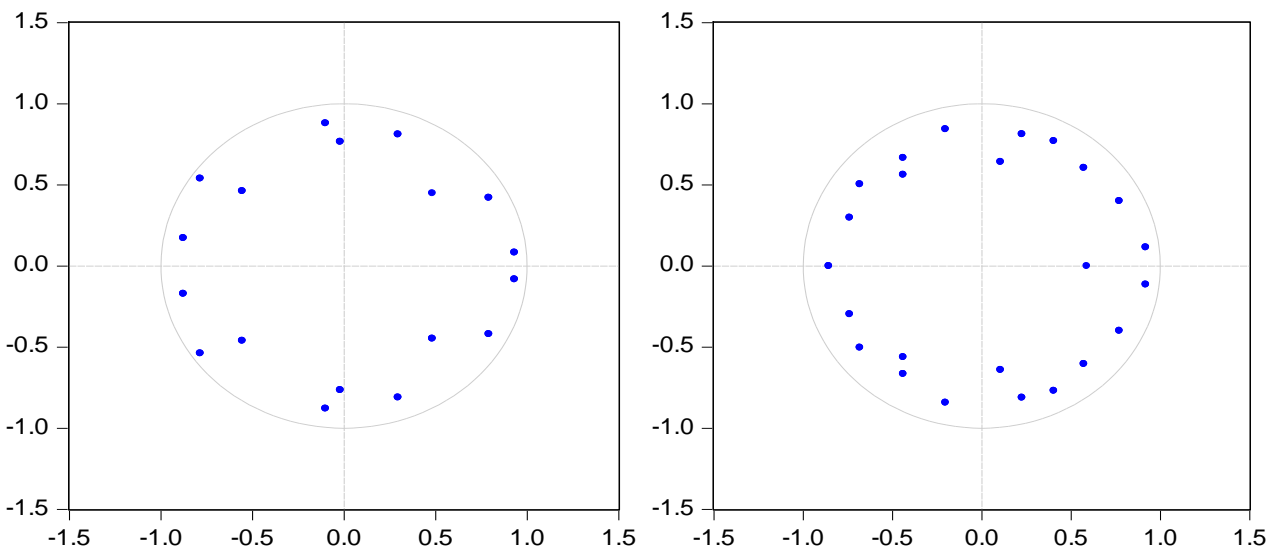

Şekil 1. Modellere Ait AR Karakteristik Polinomunun Ters Kökleri 
Kübra SAKA ILGIN, Salim Sercan SARI

COVID-19 Pandemisinin Hisse Senedi Piyasalarına Etkisi: Vaka ve Ölümlerin Yoğun

Olduğu Ülkeler ile Türkiye İncelemesi

Tablo 3. Otokorelasyon ve Değişen Varyans Testi Sonuçları

\begin{tabular}{|l|l|l|l|l|l|}
\hline \multicolumn{5}{|c|}{ Lagrange Çarpanı (LM) Otokorelasyon ve White Değişen Varyans Testi } \\
\hline & $\begin{array}{l}\text { Gecikme } \\
\text { Uzunluğu }\end{array}$ & $\begin{array}{l}\text { LM İstatistiği } \\
\text { Iest }\end{array}$ & $\begin{array}{l}\text { Olasılık } \\
\text { Değeri }\end{array}$ & $\begin{array}{l}\text { White Test } \\
\text { İstatistiği }\end{array}$ & $\begin{array}{l}\text { Olasılık } \\
\text { Değeri }\end{array}$ \\
\hline Model 1-ABD & 8 & 14.524 & 0.104 & 42.746 & 0.203 \\
\hline $\begin{array}{l}\text { Model 2- } \\
\text { HINDISTAN }\end{array}$ & 8 & 4.806 & 0.850 & 45.652 & 0.130 \\
\hline $\begin{array}{l}\text { Model 3- } \\
\text { BREZİYA }\end{array}$ & 7 & 8.432 & 0.491 & 29.876 & 0.754 \\
\hline $\begin{array}{l}\text { Model 4- } \\
\text { RUSYA }\end{array}$ & 7 & 9.211 & 0.417 & 36.239 & 0.457 \\
\hline $\begin{array}{l}\text { Model 5- } \\
\text { KOLOMBIYYA }\end{array}$ & 6 & 6.833 & 0.654 & 36.368 & 0.451 \\
\hline $\begin{array}{l}\text { Model } \\
\text { TÜRKIYYE }\end{array}$ & 8 & 15.338 & 0.082 & 28.741 & 0.532 \\
\hline
\end{tabular}

Şekil 1 ve Tablo 3 modeller için belirlenen uygun gecikme uzunluklarına göre oluşturulmuş tanı testlerinin sonuçlarını ifade etmektedir. Şekil 1'de elde edilen sonuçlar; belirlenen gecikme uzunlukları göz önünde bulundurulduğunda tüm modeller için değişkenlerin AR polinomunun ters köklerinin birim çember içinde olduğunu göstermektedir. Tablo 3 'te yer alan sonuçlar ise;ters hipoteze sahip olan LM ve White Test İstatistiği olasılık değerlerinin 0.05 'ten büyük olduğunu, dolayısıyla, uygun gecikme uzunluklarına göre oluşturulan modellerin otokorelasyon ve değişenvaryans sorunu taşımadığını ifade etmektedir.

Analizin üçüncü aşamasında, klasik VAR analizi sonucunda elde edilen optimal gecikme uzunlukları $(\mathrm{k})$, birim kök testleri sonucunda elde edilen maksimum bütünleşme derecelerine $\left(\mathrm{d}_{\max }\right)$ ilave edilerek $\left(\mathrm{k}+\mathrm{d}_{\max }\right)$ gecikmeli geliştirilmiş VAR modelleri oluşturulmuştur. Son aşamada ise VAR $\left(k+d_{\max }\right)$ modellerindeki $\mathrm{k}$ gecikmeli değerlere MWald test istatistiği uygulanarak değişkenler arasındaki nedensellik ilişkisi incelenmiştir. Wald test istatistiği sonuçlarını gösteren Toda-Yamamoto Nedensellik Analizi sonuçları Tablo 4’te özetlenmiştir. 
Tablo 4. Toda-Yamamoto Nedensellik Analizi Sonuçları

\begin{tabular}{|c|c|c|c|}
\hline Model & $\mathbf{k}+\mathbf{d}_{\max }$ & $\begin{array}{l}\text { Wald İstatistiği (Ki- } \\
\text { kare) }\end{array}$ & Nedensellik \\
\hline Model 1 & $8+1=9$ & & \\
\hline t-vaka_DOWJONES & & $77.750[0.000]$ & VAR \\
\hline t-ölüm_DOWJONES & & $108.519[0.000]$ & VAR \\
\hline Model 2 & $8+1=9$ & & \\
\hline t-vaka_BSESENSEX & & $106.299[0.000]$ & VAR \\
\hline t-ölüm_BSESENSEX & & $84.370[0.000]$ & VAR \\
\hline Model 3 & $7+0=7$ & & \\
\hline t-vaka_BOVESPA & & $138.239[0.000]$ & VAR \\
\hline t-ölüm_BOVESPA & & $80.730[0.000]$ & VAR \\
\hline Model 4 & $7+1=8$ & & \\
\hline t-vaka_MOEX & & $61.141[0.000]$ & VAR \\
\hline t-ölüm_MOEX & & $19.003[0.014]$ & VAR \\
\hline Model 5 & $6+0=6$ & & \\
\hline t-vaka_COLCAP & & $81.367[0.000]$ & VAR \\
\hline t-ölüm_COLCAP & & $19.818[0.003]$ & VAR \\
\hline Model 6 & $8+0=8$ & & \\
\hline t-vaka_BIST100 & & $19.915[0.010]$ & VAR \\
\hline t-ölüm_BIST100 & & $14.925[0.060]$ & VAR \\
\hline
\end{tabular}

[] MWALD istatistiğine ait olasılık değerlerini ifade etmektedir.

Tablo 4'te sunulanToda-Yamamoto Nedensellik analizi sonuçlarına göre; Model 1, 2, 3, 4,5 ve 6 için günlük toplam vaka ve ölüm sayılarından endekslere doğrunedensellik ilişkisi olduğu tespit edilmiştir. Bu sonuç; ABD, Hindistan, Brezilya, Rusya, Kolombiya ve Türkiye finansal piyasalarının öncü göstergeleri olan DOWJONES, BSESENSEX, BOVESPA, MOEX, COLCAP ve BİST-100 endekslerinin bu ülkelerde seçilen zaman aralığında meydana gelen COVID-19 vaka ve ölüm sayılarından etkilendiğini göstermektedir. Bu ilişkinin pandemiye bağlı toplamvaka ve ölüm sayılarının en fazla olduğu ilk beş ülkede ve özellikle dünya ekonomisine hükmeden ABD'nde dahi \%1 anlamlılık seviyesinde olduğunun tespit edilmesi pandeminin finansal ve ekonomik boyutunu göz önüne sermektedir. Ülkemizde ise bu ilişki anlamlı bulunmakla birlikte anlamlılık düzeyinin diğer ülkelere göre kısmen düşük bulunduğu ifade edilebilmektedir. 


\section{Sonuç}

2019 yılının Aralık ayında ilk olarak Çin'de ortaya çıkanve zamanladünyayısarmaya devam edenyeni tip koronavirüsCOVID-19, yaklaşık 3 ay gibi kısa bir zaman içinde Dünya Sağlık Örgütü tarafından salgın hastalık olarak duyurulmuştur. Bu tarihten sonra salgına bağlı vaka ve ölüm sayıları oldukça yüksek bir ivme kazanmıştır.10 Ekim 2020 tarihi itibarı ile dünyada bir milyonu aşkın insanın can kaybına yol açan bu salgın hastalığın neden olduğu ortam yalnız sosyal ve kültürel faaliyetleri etkilemekte kalmayıp ülke ekonomilerine, uluslararası ticarete ve ülkelerin finansal piyasalarına sekte vurmuştur. Dünyanın önde gelen ekonomilerinin borsalarında son zamanların en keskin düşüşleri yaşanmış ve uluslararası finansal piyasalarda ciddi bir panik ortamı oluşmuştur.

Bu çalışmada 18 Şubat 2020 - 30 Eylül 2020 döneminde, COVID-19pandemisinin vaka ve ölüm sayılarının en fazla olduğu ilk beş ülkenin yanı sıra Türkiye hisse senedi piyasaları ile bu ülkelerde gözlenen toplam vaka ve ölüm sayıları arasındaki nedensellik ilişkisi araştırılmıştır.Toda-Yamamoto Nedensellik Analizi kullanılarak yapılan analizde ABD, Hindistan, Brezilya, Rusya, Kolombiya ve Türkiye hisse senedi piyasalarının gösterge endekslerinin bu ülkelerdeki COVID-19 günlük toplam vaka ve ölüm sayıları arasında anlamlı nedensellik ilişkisi olduğu belirlenmiştir.COVID-19Koronavirüspandemi sürecinde gösterge endekslerin vaka ve ölüm sayılarındanetkilenmesi piyasalarda yaşanan belirsizliği ortaya koymaktadır. Tüm dünyayı etkisi altına alan pandemi sürecinde giderek artış yaşanan vaka ve ölüm sayıları küresel ekonomiye olumsuz etki etmekte ve salgının yoğun olarak yaşandığg güçlü ekonomilerin dahi savunmasız kaldıklarını göstermektedir.Pandeminin gidişatı ve belirsizlik nedeniyle bu dönemdeulusal ya da uluslararası borsalara yatırım yapma düşüncesinde olan yatırımcıların yatırım kararı almadan önce ilgili endekslerin bu süreçten ne yönde etkilendiklerini dikkate almalarınınpandemiyi firsata çevirebilmeleri açısından da son derece önemli olduğu ifade edilebilir.

Çalışmamızla parelel olarak Baker vd. (2020), Barut ve Yerdelen Kaygın (2020), Hacievliyagil ve Gümüş (2020), Kılıç (2020), Onali (2020) ile Şenol ve Zeren (2020)'nin çalışmalarında da COVID-19'un borsa endeksleri üzerinde ciddi etkileri olduğu belirlenmiştir. Barut ve Yerdelen Kaygın (2020) çalışmalarında elde etmiş oldukları vaka sayıları ile Türkiye borsası arasında belirlenen etkileşim çalışmamız ile uyumlu bir sonuç iken, ABD borsası ile vaka sayıları arasında etkileşim olmadığı bulgusu çalışmamıza aykırı bir sonuçtur. Hacıevliyagil ve Gümüş (2020) çalışmalarında elde etmiş oldukları sonuçlardan; Türkiye, İngiltere ve ABD borsalarının vaka sayılarından etkilendiği, ölüm sayılarının ise gelişmekte olan Türkiye, Rusya ve Brezilya borsalarını etkilediği bulguları çalışmamızın bulguları ile uyumludur.Fakat 
çalışmamızda hem vaka hem de ölüm sayılarının gelişmiş ve gelişmekte olan ülke ayrımı olmaksızın ele alınan tüm ülke borsalarını etkilediği tespit edilmiştir.İncelenen dönem ve uygulanan yöntemlerin farklılıkları çalışmaların bulgularında değişikliğe yol açabilse de temelde bulguların birbirine paralel olduğu ifade edilebilir.

COVID-19Koronavirüs salgınıyla yaşanan süreç boyunca finansal oynaklıkta artış yaşanmıştır. Bu durumun en önemli göstergesi VIX Korku Endeksi'nin tarihi rekor seviyelere yükselmesidir. Yatırımcı aktörlerin iyimser veya kötümser düşüncelere sahip olmasında önem arz eden söz konusu endeks,yatırım kararlarının etkin olmasına katkı sağlamaktadır. Dolayısıyla uluslararası finansal piyasalarda yaşanan tarihi dalgalanmaların pandemi sürecinde yatırımcıların doğru karar almasında piyasalara ilişkin beklentilerin göz önüne alındığı düşünülmektedir.

Pandemi kaynaklı toplam vaka ve ölüm sayıları ile uluslararası endeksler arasındaki nedenselliğin değerlendiği çalışmamızın yanı sıra ileriki çalışmalarda gelişmiş ve gelişen ülkeler ayrımı yapılarak ya da ülkelerin sektörel endekslerinin ele alındığı çeşitli araştırmalar yapılabilir. Ayrıca vaka sayılarındaki artış ve azalışların (pozitif ve negatif şokların) endekslerde ne yönde değişime neden olduğunu inceleyen asimetrik nedensellik analizlerinin kullanıldığı çalışmaların da literatürekatkı sağlayacağı düşünülmektedir.

\section{Kaynakça}

Açıkgöz, Ö., ve Günay, A. (2020). The Early Impact of the COVID-19 Pandemic on the Global and Turkish Economy. TurkishJournal of MedicalSciences, 50 (SI-1), 520-526.

Akerlof, A., ve Aron, J. (2000). Limonlar İçin Piyasa. New Jersey: Oxford Press.

Albulescu, C. (2020a). Coronavirus and Oil Price Crash. https://papers.ssrn.com/sol3/papers.cfm?abstract_id=3553452, (Erişim tarihi: 11.10.2020).

Albulescu, C. (2020b). Coronavirus and Financial Volatility: 40 Days of Fasting and Fear. https://arxiv.org/abs/2003.04005, (Erişim tarihi: 11.10.2020).

Aslam, F.,Mohmand, Y. T., Ferreira, P., Memon, B. A., Khan, M., ve Khan, M. (2020). Network Analysis of Global Stock Markets at the Beginning of the Coronavirus Disease (Covid19) Outbreak. Borsa Istanbul Review. http://http//www.elsevier.com/journals/borsaistanbul-review/2214-8450, (Erişim tarihi: 12.10.2020)

Baker, S., Bloom, N., Davis, S. J., Kost, K., Sammon, M., ve Viratyosin, T. (2020). The Unprecedented Stock Market Reaction to COVID-19. CovidEconomics: Vettedand Real-Time Papers, 1(3), 742-758.

Barut, A., ve Kaygın, C. Y. (2020). Covid-19 Pandemisinin Seçilmiş Borsa Endeksleri Üzerine Etkisinin İncelenmesi. Gaziantep Üniversitesi Sosyal Bilimler Dergisi, 19 (COVID-19 Special Issue), 59-70. 
Kübra SAKA ILGIN, Salim Sercan SARI

COVID-19 Pandemisinin Hisse Senedi Piyasalarına Etkisi: Vaka ve Ölümlerin Yoğun

Olduğu Ülkeler ile Türkiye İncelemesi

Beck, T. (2020). Finance in the Times of Coronavirus. Economics in the Time of COVID-19, CEPR Press.

Çetin, A. C. (2020). Koronavirüs (Covid-19) Salgınının Türkiye'de Genel Ekonomik Faaliyetlere ve Hisse Senedi Borsa Endeksine Etkisi. Mehmet Akif Ersoy Üniversitesi Uygulamalı Bilimler Dergisi, 4(2), 341-362.

Ekren, A. (2020). COVID-19'un Dünya Ekonomisine Etkisi: İran Örneği. http://http//www.academia.edu.tr, (Erişim tarihi: 12.10.2020)

Engle, R. F., ve Granger, C. W. (1987). Co-Integration and Error Correction: Representation, Estimation, Andtesting. Econometrica: journal of theEconometricSociety, 251-276.

Erik, B., Lombardi, M. J., Mihaljek, D., ve Shin, H. S. (2020). Thedollar, Bank Leverage and Real Economic Activity: An Evolving Relationship.

Gillani, S. Y. M.,Rehman, H. U., ve Gill, A. R. (2009). Unemployment, Poverty, Inflation And Crimenexus: Cointegration and Causality Analysis of Pakistan. Pakistan Economic and Social Review, 79-98.

Göker, İ. E. K., Eren, B. S., ve Karaca, S. S. (2020). The Impact of the COVID-19 (Coronavirus) on The Borsa Istanbul Sector Index Returns: An Event Study. Gaziantep Üniversitesi Sosyal Bilimler Dergisi, 19 (COVID-19 Special Issue), 14-41.

Granger, C. W. (1969). Investigating Causal Relations by Econometric Models And CrossSpectral Methods. Econometrica: journal of theEconometricSociety, 424-438.

Güler, H. N. (2020). Koronavirüsü (COVID-19) Günlerinde Bankalara İletilen Müşteri İtiraz Ve Şikayetlerinin İncelenmesi. Avrasya Sosyal ve Ekonomi Araştırmaları Dergisi, 7(4), 8599.

Gülhan, Ü. (2020). Covid-19 Pandemisine BIST 100 Reaksiyonu: Ekonometrik Bir Analiz. Electronic TurkishStudies, 15(4), 497-509.

Gümüş, A., ve Hacıevliyagil, N. (2020). Covid-19 Salgın Hastalığının Borsaya Etkisi: Turizm ve Ulaştırma Endeksleri Üzerine bir Uygulama. Akademik Yaklaşımlar Dergisi, 11(1), 7697.

Hacıevliyagil, N., ve Gümüş, A. (2020). Covid-19'un En Etkili Olduğu Ülkelerde Salgın-Borsa İlişkisi. Gaziantep Üniversitesi Sosyal Bilimler Dergisi, 19(COVID-19 Special Issue), 354-364.

Johansen, S., ve Juselius, K. (1990). Maximum Likelihood Estimation and In Ference on Cointegration-With Appucations to the Demand Formoney. Oxford Bulletin of Economicsandstatistics, 52(2), 169-210. 
Kılıç, Y. (2020). Borsa İstanbul'da COVID-19 (Koronavirüs) Etkisi. JOEEP: Journal ofEmergingEconomiesandPolicy, 5(1), 66-77.

McKibbin, W. J., ve Fernando, R. (2020). The Global Macro Economic Impacts of COVID-19: Seven Scenarios. Australian National University Working Paper, 19, 1-45.

Onali, E. (2020). COVID-19 and Stock Market Volatility. https://ssrn.com/abstract=3571453 $(13.10 .2020)$

Özdemir, L. (2020). COVID-19 Pandemisinin BISST Sektör Endeksleri Üzerine Asimetrik Etkisi. Finans Ekonomi ve Sosyal Araştırmalar Dergisi, 5(3), 546-556.

Öztürk, Ö., Şişman, M. Y., Uslu, H., ve Çıtak, F. (2020). Effect of COVID-19 Outbreak on Turkish Stock Market: A Sectoral-Levelanalysis. Hitit UniversityJournal of Social Sciences Institute, 13(1), 56-68.

Peiro, A. (2016). Stock Prices and Macro Economic Factors: Some Europe an Evidence. International Review of Economics\& Finance, 41, 287-294.

Sharif, T.,Purohit, H., ve Pillai, R. (2015). Analysis of Factors Affecting Share Prices: The Case of Bahrain Stock Exchange. International Journal of Economicsand Finance, 7(3), 207216.

Şenol, Z., ve Zeren, F.(2020), Coronavirus (COVID-19) And Stock Markets: The Effects Of ThePandemic On The Global Economy. Avrasya Sosyal ve Ekonomi Araştırmalar Dergisi, 7(4), 1-16.

Tayar, T., Gümüştekin, E., Dayan, K. ve Mandi, E. (2020). Covid-19 Krizinin Türkiye'deki SektörlerÜzerindeki Etkisi: Borsa İstanbul Sektör Endeksleri Araştırması. Van Yüzüncü Yll Üniversitesi Sosyal Bilimler Üniversitesi Dergisi, Salgın Hastalıkları Özel Sayı,293320.

Toda, H. Y., ve Yamamoto, T. (1995). Statistical Inference in Vector Autoregressions with Possibly Integrated Processes. 66, 225-250.

Üstün, Ç., ve Özçiftçi, S. (2020). COVID-19 Pandemisinin Sosyal Yaşam Ve Etik Düzlem Üzerine Etkileri: Bir Değerlendirme Çalışması. Anadolu Kliniği Tip Bilimleri Dergisi, 25 (Special Issue on COVID 19), 142-153.

Yenilmez, F. ve Erdem, M. S. (2018). Türkiye ve Avrupa Birliği'nde Ekonomik Büyüme ile Enerji Tüketimi Arasındaki İlişki: Toda-Yamamoto Nedensellik Testi, Eskişehir Osmangazi Üniversitesi Sosyal Bilimler Dergisi, 19(1), 71-95.

Zeren, F., ve Hizarc1, A. (2020). TheImpact Of COVID-19 Coronavirus On Stock Markets: Evıdence From Selected Countries. Muhasebe ve Finans Incelemeleri Dergisi, 3(1), 7884. 
Kübra SAKA ILGIN, Salim Sercan SARI

COVID-19 Pandemisinin Hisse Senedi Piyasalarına Etkisi: Vaka ve Ölümlerin Yoğun

Olduğu Ülkeler ile Türkiye İncelemesi

Zhang, D., Hu, M., ve Ji, Q. (2020). Financial Markets Under the Global Pandemic of COVID19. Finance Research Letters, 101528, 1-6.

https://tr.investing.com (Erişim tarihi: 02.10.2020)

https://www.worldometers.info (Erişim tarihi: 06.10.2020) 